\title{
Corporate Governance, Strategic Choices and Performance of Financial Institutions in Kenya
}

\author{
Grace Kamau ${ }^{1}$, Evans Aosa ${ }^{2}$, Vincent Machuki ${ }^{2} \&$ Ganesh Pokhariyal $^{3}$ \\ ${ }^{1}$ Director, Finance and Strategy, Institute of Certified Public Accountants of Kenya- ICPAK, Nairobi, Kenya \\ ${ }^{2}$ Professor of Strategic Management, School of Business, University of Nairobi, Kenya \\ ${ }^{2}$ Senior Lecturer, School of Business, University of Nairobi, Kenya \\ ${ }^{3}$ Professor of Applied Mathematics, University of Nairobi, Kenya \\ Correspondence: Grace Kamau, Finance and Strategy, Institute of Certified Public Accountants of Kenya- ICPAK, \\ Nairobi, Kenya. E-mail: gkamau2008@gmail.com
}

Received: March 30, 2018

doi:10.5539/ijbm.v13n7p169
Accepted: April 30, 2018

Online Published: June 15, 2018

URL: https://doi.org/10.5539/ijbm.v13n7p169

\begin{abstract}
It has been argued that corporate governance plays a critical role in determining the strategic direction of corporations. This is achieved through formulation of strategic choices that utilizes firm's internal resources to align corporations to the external environment for optimal performances. In this study, we sought to determine the influence of corporate governance and strategic choices to the performance of financial institutions in Kenya. A cross sectional descriptive research design was adopted and, primary data collected from top executives of 108 financial institutions. We analyzed data using regression analysis. Results indicate that corporate governance and strategic choices significantly influences organizational performance. Further, the study revealed a partial mediation of strategic choices to corporate governance and organizational performance. It was concluded that besides corporate governance being a key determinant of performance in organizations, adoption of appropriate strategic choices greatly enhances the performance. The results are important to organizational leaders, policy makers, investors and all corporate stakeholders in determining optimal strategies for organizational posterity.
\end{abstract}

Keywords: corporate governance, strategic choices and organizational performance

\section{Introduction}

The ultimate growth and success of corporations is largely determined by the strategic choices adopted. Actualization of these strategic choices typically depends on the governance framework embraced by organizational leaders. As such, corporate governance lays foundation for optimal utilization of firms' resources through formulation of strategies that aligns with the environment (Daily, Dalton, \& Cannella, 2003). These strategies are largely sanctioned by board of directors, making them a key pillar in corporate governance (Kiel \& Nicholson, 2003). Further, codes of corporate governance grants directors the formal authority to ratify management's initiatives, evaluate their performance, determine corporations purpose, ethics and strategic direction (OECD, 2004; CMA, 2015). Intrinsically, as directors engage in strategic management processes, each board member's perception and interpretation of strategic issues facing corporations subsequently affects strategic choices championed (Hambrick, 2007). Ultimately, these strategic choices impact firm's performance and organization's value.

Strategic choices have been highlighted as the vehicles through which organizations align to the environment thus enhancing performance. Scholars have long recognized that firms' survival and success depend on both environmental forces and strategic choices (Child, 1972; Judge et al., 2015). The alternatives made depends on variety of contextual influences arising from past events, present circumstances, and perspectives of the future (March, 1991). Strategic choices are the optimal objectives that a firm adopts to pursue value maximization. It is also viewed as the espousal of intended courses of actions by an organization, in consideration of available resources and required commitment (Van den Steen, 2013). Thus, strategic choices enhance clarity of generic strategy and organization's strategic intent thereby leading to high performance (Parnell, 2013). Supporting generic strategies are specific primary or secondary strategies that are either internal or external related.

Corporate governance has been identified as a key catalyst, influencing how strategic choices affect performance 
in organizations. This is achieved through linking firms' mission and vision to the strategic choices made. As such, good governance is a key determinant of the strategies adopted by firms and their implementation. Through good governance, corporate strategies are aligned to organizations internal processes and prevailing external environmental forces. Another key role played by good governance is matching of corporate strategic choices for optimal utilization of firms' resources (Daily, et al., 2003). It is argued that boards of directors are taking a more central oversight role in running organizations. As a result, board's performance is directly linked to the firms' performance (Pettigrew, 1992). Thus, researchers and practitioners have sought better understanding of the processes and behaviors involved in effective board performance. Some of the considerations sought include board demographics, composition and skills (Forbes \& Milliken, 1999).

Despite all the evidence that links corporate governance to strategic choices for enhanced performance, inconclusive and inconsistent conceptual and empirical findings have been recorded. On one hand, board of directors have been viewed as responsible in directing corporation's strategic direction for value maximization (Holderness, 2003; Carpenter \& Westphal, 2001; Pugliese et al., 2009). A contrary perspective views board members as passive in strategy making and subject to management and CEO's manipulation (Lipton \& Lorsch, 1992). Further, while Heracleous (2001) argued that board influences strategic choices and their implementation, consequently affecting firm performance, Essen, Oosterhout and Carney (2011) recorded no association between firm's governance stance, and strategic choices adopted to performance. These inconsistencies led to the need for further interrogation on how these variables interact thus the impetus for the study. In this study, corporate governance was viewed from the various manifestations that include code of corporate governance, board skills, independence, diversity, size and board committees. Strategic choices comprised alliances, mergers, acquisitions, diversifications, divestments, adoption of information technology, innovation and product development. Further, performance was analyzed using the six perspectives of sustainable balanced scorecard (SBSC); financial, customer focus, internal processes, growth and development, social issues and environmental consciousness.

\subsection{Literature Review and Conceptual Hypothesis}

In this study, industrial organization economics (IOE) theory was adopted for conceptualizing the linkage between corporate governance, strategic choices and organizational performance. We found IOE theory to be most suitable because of its structure-conduct-performance (S-C-P) paradigm as suggested by Bain (1956) and Porter (1981). The theory emphasizes that industry structure determines firm conducts, which in turn determines its performance (Scherer, 1980; Conner, 1991). The conduct is viewed as firm's choice of key strategies which are vital economic dimensions for performance (Porter, 1981). Structure provides stability in economic and technical environment in which firms compete. Further, the structure determines the conduct to be adopted. These include information communication technology (ICT) embraced, degree of product differentiation, level of integration and barriers to entry (Porter, 1981; Scherer, 1980). In the current study, among key strategies adopted by financial institutions to enhance performance include strategic alliances, mergers and acquisitions, products differentiation, adoption of information technology for transacting which significantly reduces operational costs and enhancing innovativeness. The respective industry structure and conduct sets the regulatory framework to be adopted by all organizations.

Further, they determine the governance mechanisms to be adhered to. This is achieved through formulation of codes of corporate governance at firm, industry and sector levels. In this study IOE theory is further complimented by stakeholder theory. The theory recognizes that firms operate within an environment composed of different interest groups aside of the immediate owners, with diverse interests (Harrison \& Wicks, 2013). Thus, there is needed to take all their interests into consideration while making corporate strategic decisions (Freeman, 1984; Lawal, 2012). Further, organizations are expected to expand their fiduciary duty to the local community and the environment in which they operate (Freeman, 1984). Thus, stakeholder theory provides a mechanism for connecting ethics and strategy. Therefore, firms that diligently seek to serve the interests of a broad group of stakeholders creates more value overtime leading to high performance (Freeman, 1984; Harrison \& Wicks, 2013). This study views the role of organizational leaders, as that of making optimal strategic choices that maximizes firm value for all stakeholders.

Strategic choices are viewed as the optimal objectives that a firm adopts to pursue for value maximization. It is also viewed as the espousal of intended courses of actions by an organization, in consideration of available resources, required commitment, persistence, irreversibility and presence of uncertainty (Van den Steen, 2013). The objectives are recognized as strategic when they represent matters of importance to an organization particularly, those bearing upon its ability to prosper in a competitive environment or where there is needs to maintain credibility (Child, 1997). Strategic choices are also regarded as the goals and plans that an organization sets to adapt and to align with the internal and external environment. It can also be viewed as the outcome of the 
intent and analysis of options available in reflection of the feasibility, prudence, consensus and acceptability (Gellerman \& Potter, 1996).

Further, organizations exist to create value for stakeholders to posterity. This is achieved through accomplished corporate governance structures and practices. Structures identify distribution of rights and responsibilities among various corporate stakeholders (Aguilera \& Jackson, 2003). In addition, corporate governance practices involve board operations such as appointment, functioning, compensation and directing corporations' strategic direction (CMA, 2015; OECD 2004). Subsequently, as directors engage in strategic management processes, each board member's perception and interpretation of strategic issues facing the organization affects strategic choices made (Hambrick, 2007). As such, various attributes of the board permeate firms core strategic decisions. Once these strategic decisions are actualized, they dictate the level of performance and the overall value of the firms. It is therefore important to consider individual board members' attributes at appointment to ensure a mix of competences and diversity required. Some of these attributes include board composition, board independence, board sizes, busy directors serving in multiple boards and board members individual characteristics (Dewji \& Miller, 2013).

The discussion on board involvement to strategy has been fuelled by a combination of contextual factors, alternate theoretical perspectives, and inconclusive empirical results. Machuki and Aosa (2011) found organizations performance to be influenced by strategic behavior adopted in response to external environment. As such, organizational effectiveness depends, in part, on achieving a match between control strategies and the strategic context of the firm (Hoskisson, 1987). Holderness (2003) argued that boards are responsible for developing firm's nexus of contracts thereby aligning the actions and choices of managers with the interests of shareholders. Moreover, board of directors are argued to be legally responsible for the strategy of firms. This is due to their leadership position to direct firm's strategic direction hence influencing the outcomes (Carpenter \& Westphal, 2001; Pugliese et al., 2009).

On the contrary boards are perceived to be passive in firms' strategy and subject to CEO's and executives' manipulation (Lipton and Lorsch, 1992). Furthermore, anecdotal evidence suggests that boards might destroy value when they become involved in strategy, due to their distance from day-to-day firm operations (Jensen, 1993). In addition, the presence of information asymmetries, and the need for board to remain independent contributes in making them inert to firm's strategy making (Hendry and Kiel, 2004). Further, it is argued that boards' participation in strategic decisions would make them co-responsible thus jeopardizing the required distance between board members and managers (Boyd, 1995). It emerges, there is no consensus whether board of directors does or should execute their strategic decisions roles effectively, thus leading to the need for further interrogation. Further, limited literature exists elaborating how corporate governance influences firm performance. It is argued that strategic choices align organizations' mission and vision, to the operating environmental forces. Yet, the intervening effect of strategic choices to the relationship between corporate governance and firm performance remains unsettled. This lead to the question, does strategic choices significantly intervene the relationship between corporate governance and organizational performance in Kenya's financial Institutions?

Thus, the objective of this study was to establish the effect of strategic choices on the relationship between corporate governance and organizational performance. Strategic choices were viewed as the mechanisms through which board of directors influence organizational performance. As such, strategic choices would intervene the relationship between corporate governance and organizational performance. This objective was presented by the hypothesis below;

$H_{I}$ : Strategic choices significantly intervenes the relationship between corporate governance and organizational performance.

\section{Methods}

This study used cross-sectional descriptive research design necessitated by the need to describe the variables interaction's between and across the four categories of financial institutions (Zohrabi, 2013). This design attempts to define and describe study subjects by classifying them into various categories and relating the variables' interaction. In this study, financial institutions were categorized into four sub categories, that is, banks, micro finance institutions (MFIs), insurance companies and deposit taking SACCOs. The ideal sample size was determined in consideration of data homogeneity, the level of precision required and the desired degree of 
confidence. Thus, we used Israel's (1992) formula; $\mathrm{n}=\frac{N}{1+N e^{2}}$ where $\mathrm{n}=$ sample size; $\mathrm{N}$ the population size and e the error term of 0.05 ( 95 percent confidence level). From a population of 271 financial institutions a sample of 162 was established to be ideal for the study. Subsequently, the identified sample size was distributed across the financial institutions as follows: banks 40, MFIs 12, insurance companies 55 and 55 deposit taking SACCOs.

We developed a semi-structured questionnaire for collecting primary data. The questionnaire was segregated along four main sections that included organization's demographics, corporate governance, strategic choices and organizational performance. The questionnaire was issued to one top executive in each sampled financial institution. Response was received from 108 financial institutions as analyzed in Table 1.

Table 1. Sample distribution and response rate

\begin{tabular}{llll}
\hline Category & Population & Sampled & Respondents \\
\hline Banks & 40 & 40 & 38 \\
MFIs & 12 & 12 & 12 \\
Insurance Companies & 55 & 55 & 25 \\
Deposit Taking SACCOs & 164 & 55 & 33 \\
Total & $\mathbf{2 7 1}$ & $\mathbf{1 6 2}$ & $\mathbf{1 0 8}$ \\
\hline
\end{tabular}

The three variables of the study were corporate governance, strategic choices and organizational performance. Corporate governance was operationalized along the six dimensions that included code of corporate governance, board skills, independence, size, committees and diversity. The second variable entailed key strategic choices adopted by financial institutions such as strategic alliance, mergers and acquisition, diversification, divestment, ICT adoption, products development and innovation. The sustainable balanced scorecard (SBSC) operationalized organizational performance along the six perspectives of financial, customer focus, internal business processes, learning and growth, social equity, environmental consciousness. Composite indices of each variable were used for regression modelling.

The analysis was undertaken using Baron and Kenny's (1986) four steps regression model. The first step involved regressing corporate governance on organizational performance. The second step entailed regressing corporate governance on strategic choices. In the third step, strategic choices were regressed on organizational performance. Finally, both corporate governance and strategic choices were regressed on organizational performance. These are summarized below.

Stepwise Regression

Step 1: $\mathrm{OP}_{1}=\beta_{10}+\beta_{11} \mathrm{CG}+\varepsilon$

Step 2: $\mathrm{SC}=\beta_{20}+\beta_{21} \mathrm{CG}+\varepsilon$

Step 3: $\mathrm{OP}_{3}=\beta_{30}+\beta_{31} \mathrm{SC}+\varepsilon$

Step 4: $\mathrm{OP}_{4}=\beta_{40}+\beta_{41} \mathrm{CG}+\beta_{42} \mathrm{SC}+\varepsilon$

Where:

$\mathrm{OP}=$ Organizational Performance

$\beta_{10,20,30,40}=$ Regressions Constant

$\mathrm{CG}=$ Corporate Governance

$\mathrm{SC}=$ Strategic Choices

$\varepsilon=$ Error Term

$\beta_{11,21,31,41,42}$ are coefficient's

Further, Intervention was tested using path analysis. The path analysis model is presented by Figure1. 


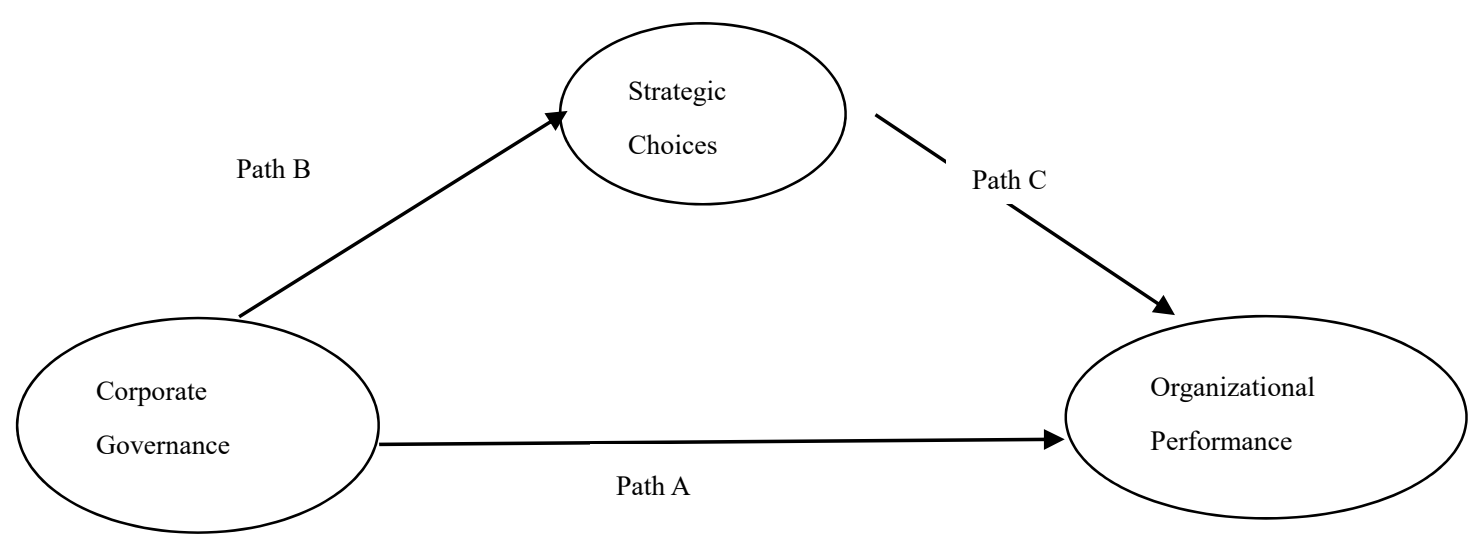

Figure 1. Path Analysis

Path A depicts the direct relationship between corporate governance and organizational performance. This relationship was found to be significant. Path B shows interaction between corporate governance and strategic choices. In path $\mathrm{C}$, both corporate governance and strategic choices' effect on organizational performance was outlined.

\section{Results}

Out of a sample size of 162 financial institutions, 108 responded with analyzable data, translating to $67 \%$ response rate. Data were collected from the top executives of financial institutions including the CEO, the company secretaries and the directors. We found the financial institutions to be leanly staffed, $58 \%$ having below 250 permanent employees. Only about 10 percent had above 1000 permanent staff. Further, the data was found to be highly reliable as demonstrated by Cronbach's Alpha of between 0.78 to 0.92 . Results also confirmed data validity through factor analysis.

The results obtained on stepwise regression analysis are presented in Tables 2(a) through 2(d). Intervention step 1 involved regressing corporate governance on organizational performance. Results are presented in Table 2 (a).

Table 2(a). Step 1 of intervening effect of strategic choices on corporate governance and organizational performance

\begin{tabular}{|c|c|c|c|c|c|c|c|c|c|}
\hline \multicolumn{10}{|c|}{ Model Summary } \\
\hline Model & $\mathrm{R}$ & R Square & \multicolumn{2}{|c|}{ Adjusted R Square } & Std. Error of & \multicolumn{2}{|c|}{ theDurbin-Watson } & & \\
\hline 1 & .4 & .202 & .192 & & 2.46927 & 1.945 & & & \\
\hline \multicolumn{10}{|c|}{ ANOVA } \\
\hline \multirow[t]{2}{*}{ Model } & & Sum of & uares & $\mathrm{df}$ & Mean Square & $\mathrm{F}$ & Sig. & & \\
\hline & Regression & 121.965 & & 1 & 121.965 & 20.003 & .000 & & \\
\hline \multirow[t]{2}{*}{1} & Residual & 481.685 & & 79 & 6.097 & & & & \\
\hline & Total & 603.650 & & 80 & & & & & \\
\hline \multicolumn{10}{|c|}{ Coefficients } \\
\hline \multirow[t]{3}{*}{ Model } & & \multicolumn{3}{|c|}{ Unstandardized Coefficients } & Standardized & \multirow[t]{3}{*}{$\mathrm{t}$} & \multirow[t]{3}{*}{ Sig. } & \multirow{2}{*}{\multicolumn{2}{|c|}{ Collinearity Statistics }} \\
\hline & & & & & Coefficients & & & & \\
\hline & & $\mathrm{B}$ & & Std. Erro & Beta & & & Tolerance & VIF \\
\hline & (Constant) & 7.091 & & 2.728 & & 2.600 & .011 & & \\
\hline 1 & $\begin{array}{l}\text { Corporate gov } \\
\text { (IV) }\end{array}$ & rnance 202 & & .045 & .449 & 4.472 & .000 & 1.000 & 1.000 \\
\hline
\end{tabular}

a. Dependent Variable: Organizational performance (DV)

b. Predictors: (Constant), Corporate governance (IV).

Results indicate that 20.2 percent $\left(\mathrm{R}^{2}=0.202\right)$ variation in organizational performance is explained by corporate governance. The model was statistically significant and robust with $F$ value of 20.003 and $p$ value of 0.000 $(\mathrm{p}<0.05)$. Moreover, the beta coefficient predicted that for every 1 percent change in corporate governance, 
organizational performance changed by 0.449 . Thus, confirming a strong relationship in the first model In step 2, corporate governance was regressed on strategic choices and results presented in Table 2 (b).

Table 2 (b). Step 2 of intervening effect of strategic choices on corporate governance and organizational performance

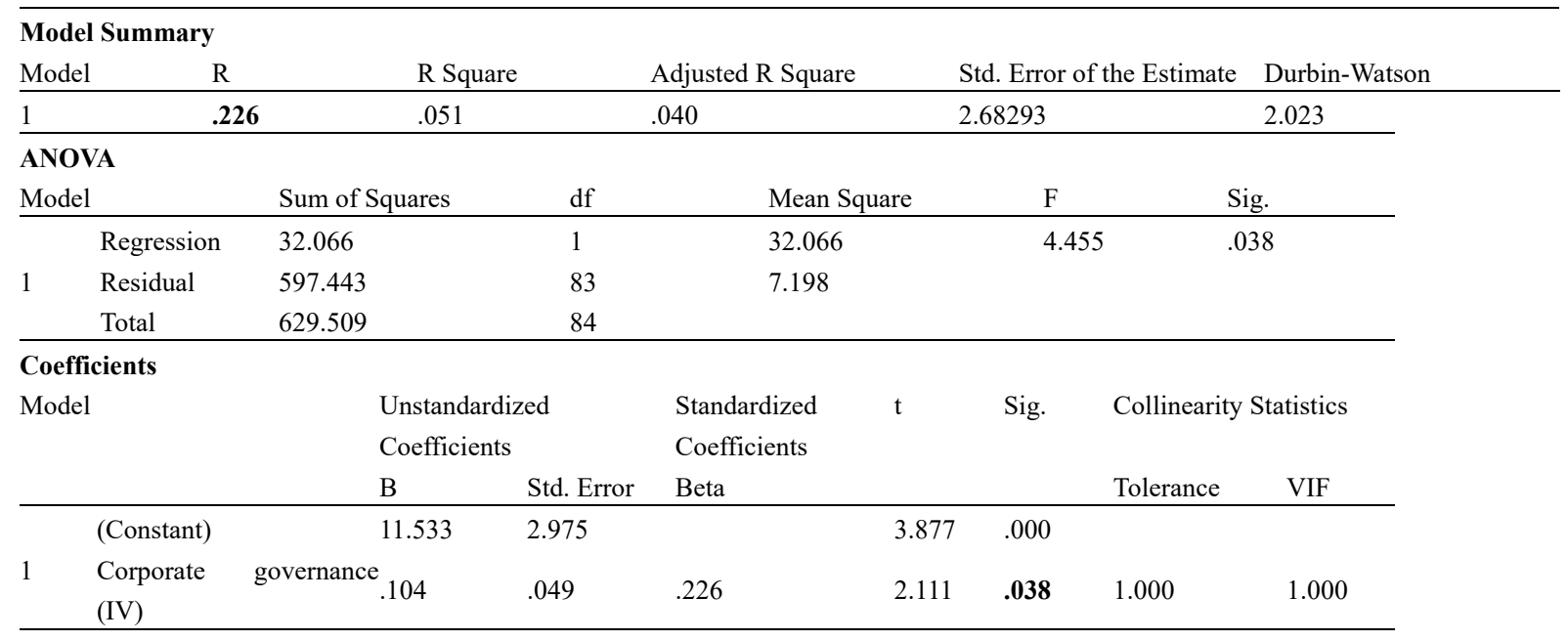

a. Predictors: (Constant), Corporate governance (IV)

b. Dependent Variable: Strategic choice (Intervener).

Results indicate that 5.1 percent $\left(\mathrm{R}^{2}=0.051\right)$ percent variation in strategic choices was explained by corporate governance. The model was significant with $F$ statistics of 4.455 and $p$ value of $0.038(p<0.05)$ depicting a robust model. In the third step, strategic choices were regressed on organizational performance. Results are presented in Table 2 (c).

Table 2 (c). Step 3 of intervening effect of strategic choices on corporate governance and organizational performance

\begin{tabular}{|c|c|c|c|c|c|c|c|c|}
\hline \multicolumn{9}{|c|}{ Model Summary } \\
\hline \multirow{2}{*}{$\begin{array}{l}\text { Model } \\
1\end{array}$} & $\mathrm{R}$ & R Square & \multicolumn{2}{|c|}{ Adjusted R Square } & Std. Error of the Estimate & \multicolumn{3}{|c|}{ Durbin-Watson } \\
\hline & .511 & .261 & .252 & & 2.39148 & 1.940 & & \\
\hline \multicolumn{9}{|c|}{ ANOVA } \\
\hline \multirow[t]{2}{*}{ Model } & & \multicolumn{2}{|c|}{ Sum of Squares } & & df Mean Square & $\mathrm{F}$ & Sig. & \\
\hline & Regressior & \multicolumn{2}{|c|}{173.529} & & $1 \quad 173.529$ & 30.341 & .000 & \\
\hline \multirow[t]{2}{*}{1} & Residual & \multicolumn{2}{|c|}{491.851} & & 865.719 & & & \\
\hline & Total & \multicolumn{2}{|c|}{665.380} & & 87 & & & \\
\hline \multicolumn{9}{|c|}{ Coefficients } \\
\hline \multirow[t]{2}{*}{ Model } & & & \multicolumn{2}{|c|}{ Unstandardized Coefficients } & Standardized Coefficients & $\mathrm{t}$ & Sig. Collinearit & atistics \\
\hline & & & $\mathrm{B}$ & Std. Error & Beta & & Tolerance & VIF \\
\hline \multirow{2}{*}{1} & (Constant) & & 10.261 & 1.656 & & 6.195 & .000 & \\
\hline & Strategic c & (Intervener) & .510 & .093 & .511 & 5.508 & .0001 .000 & 1.000 \\
\hline
\end{tabular}

a. Dependent Variable: Organizational performance (DV).

b. Predictors: (Constant), Strategic choice (Intervener).

The results obtained $(\mathrm{R} 2=0.261, \mathrm{p} \leq 0.05, \mathrm{~F}$ statistics $=30.341)$ as presented in Table 2 (c) indicate that the relationship between strategic choices and organizational performance was statistically significant. In this model, strategic choices explained 26.1 percent of the variation in organizational performance. The $p$ value of 0.000 and F statistics of 30.341 depicts a robust and significant model explaining relationship between the variables. Consequently, the analysis proceeded to step four (4).

In the final step (4) both the independent variable (corporate governance) and intervening variable (strategic 
choices) were regressed on dependent variable (organizational performance). The results presented in Table 2 (d) demonstrate that there was statistically significant intervention by strategic choices on the relationship between corporate governance and organizational performance. Further, the results indicate that both the independent variable (model 1) and intervening variable (model 2) were also statistically significant. This implies partial mediation/ intervention.

Table 2(d). Step 4 of intervening effect of strategic choices on corporate governance and organizational performance

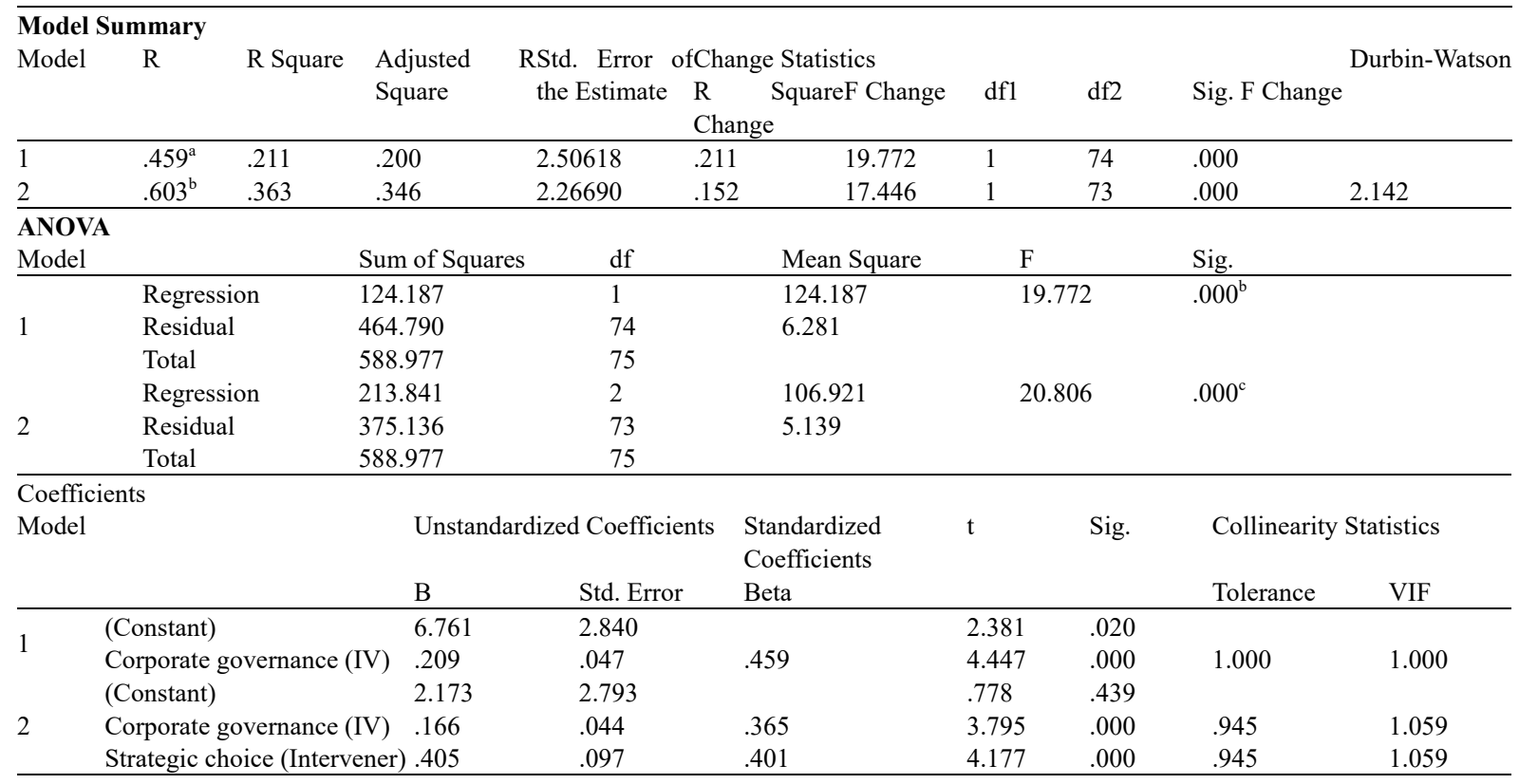

a. Predictors: (Constant), Corporate governance (IV).

b. Predictors: (Constant), Corporate governance (IV), Strategic choice (Intervener)

c. Dependent Variable: Organizational performance (DV).

Inspection of the model summary in Table $2(d)$ demonstrate a significant change in $R$ square $\left(\Delta R^{2}=15.2\right)$ from 21.1 percent to 36.3 percent revealing evidence of mediation. The beta coefficient of $0.401(\beta=0.401)$ imply that for every 1 percent change in strategic choices, there was a variation of 0.401 percent in organizational performance. The $F$ statistics of 20.806 and $p$ value of $p=0.000$ (below $p \leq 0.005$ ) affirms a strong, statistically significant model. Thus, the hypothesis was supported.

Additional tests for intervention were done using two panels of Pearson correlation matrix. The first panel involved testing the relationship between corporate governance and strategic choices. In this panel, corporate governance was the predictor variable while strategic choices were the outcome variable. In panel two, strategic choices become the predictor variable while organizational performance was the outcome variable. The results are presented in Tables 3(a) and 3 (b) where both the correlation matrices were positive.

Table 3(a). Results of correlation for panel 1

\begin{tabular}{llll}
\hline Correlations & & Corporate governance (IV) & Strategic choice (Intervener) \\
\hline \multirow{2}{*}{ Corporate governance (IV) } & Pearson Correlation & 1 & $.226^{*}$ \\
& Sig. (2-tailed) & & .038 \\
& $\mathrm{~N}$ & 91 & 85 \\
Strategic choice (Intervener) & Pearson Correlation & $.226^{*}$ & 1 \\
& Sig. (2-tailed) & .038 & 101 \\
\hline
\end{tabular}

*. Correlation is significant at the 0.05 level (2-tailed).

Table 3 (a) presents result for correlation matrix for corporate governance and strategic choices. Results indicate 
there was a significant positive correlation between corporate governance and strategic choices. However, a weak correlation was observed at Pearson correlation value of 0.226 . The significance level was $0.05(\mathrm{P} \leq 0.05)$.

Panel 2 correlation matrix was testing the relationship between strategic choice and organizational performance. The results are presented in Table 3(b) revealing a significant positive correlation between the two variables. The Pearson correlation value of 0.511 indicate a strong relationship between strategic choices and organizational performance. The model was tested at 0.05 level of significance. The results of the two-correlation matrix were both significant, supporting intervening effect of strategic choices to the relationship between corporate governance and organizational performance.

Table 3(b). Results of correlation for panel 2 correlations

\begin{tabular}{|c|c|c|c|c|}
\hline & & $\begin{array}{l}\text { Strategic } \\
\text { (Intervener) }\end{array}$ & $\begin{array}{l}\text { ChoicesOrganizational } \\
\text { (DV) }\end{array}$ & Performance \\
\hline \multirow{3}{*}{ Strategic choice (Intervener) } & Pearson Correlation & 1 & $.511^{* *}$ & \\
\hline & Sig. (2-tailed) & & .000 & \\
\hline & $\mathrm{N}$ & 101 & 88 & \\
\hline \multirow{3}{*}{ Organizational performance (DV) } & Pearson Correlation & $.511^{* *}$ & 1 & \\
\hline & Sig. (2-tailed) & .000 & & \\
\hline & $\mathrm{N}$ & 88 & 94 & \\
\hline
\end{tabular}

**. Correlation is significant at the 0.01 level (2-tailed).

\section{Discussion}

Corporate governance plays a critical role in determining the strategic direction for corporations. Board of directors is responsible for formulating and sanctioning firms' key strategies (Carpenter \& Westphal, 2001). As such, scholars and practitioners have generally acknowledged the importance of adequate board control and independence in effectively executing their strategic decision making roles (Jensen \& Zajac, 2004). The current study sought to examine the intervening effect of strategic choices to the relationship between corporate governance and organizational performance. This was achieved by analyzing the extent to which the financial institutions in Kenya adopted the various strategic choices. These included mergers, acquisitions, strategic alliances, diversifications, divestiture, innovation, technology adoption, and products or services development. The results revealed a significant partial mediation of strategic choices to corporate governance and organizational performance. This suggest that corporate governance through strategic choices as a conduit influences firm performance. This was consistent with other studies that have shown a strong relationship between corporate governance, strategic choices and organizational performance. Heracleous (2001) argued that board influences strategic choices and implementation, consequently affecting firm performance. The study however, cautioned against excessive regulation on corporate governance, to avoid too restrictive and impractical adoption and implementation. On the contrary, Essen, Oosterhout and Carney (2011) found no statistically significant mediation by strategic choices on the relationship between governance and organizational performances.

The findings of the current study point towards two key issues. First, the statistically significant partial mediation of strategic choices on corporate governance and organizational performance imply that adoption of corporate governance by firms enhances their performance even without any form of strategic planning. This further underscores the importance of corporate governance in corporations that extends beyond defining organizations strategic direction such as enhanced disclosure, risk mitigation and resources acquisition. In addition, corporate governance brings about efficiency, business ethics and corporate citizenship that all enhances value in organizations.

Secondly, the study highlights the importance of strategic choices in determining firm performance. It demonstrates that by formulating and adopting optimal strategic options, organizations can greatly enhance their wealth and higher value. The study accentuates the important role of board of directors in formulating and sanctioning the strategic direction of corporations. Board of directors is viewed as the linkage between organization's financiers and those that use the capital to create value. Therefore, the most effective way of achieving optimal performances is through formulating and sanctioning optimal strategic choices. This study offered valuable insights to policy makers, regulators, investor and management of financial institutions. The study highlights that good governance coupled with adoption of key strategies in financial institutions can lead to 
optimal performance.

\section{Conclusion}

The findings of this study revealed strategic choices to be a key conduit in which corporate governance, through board of directors' influences performance in organizations. In the study, a significant variation in performance of financial institutions was explained by both corporate governance and strategic choices. The study suggests that one of the key roles of successful boards is to set out the strategic direction of corporations. This should be entrenched in the appointment, code of corporate governance and performance evaluation of boards. Further, the findings insinuate that corporations should evaluate their internal and external environments when formulating strategic choices. This means, that one-size-fits-all strategies would not optimize performance in all corporations, even within the same industry.

The study provides important insights to players and investors. The analysis of the adoption of corporate governance and strategic choices in the financial sector was a key indicator of critical areas to improve and what to maintain. Further, the study points to areas that need greater emphasis by the various industries. The study also informs future strategic choices that financial institutions can adopt, such as strategic alliances, mergers and acquisitions with the most compatible players within the industry and sector. The study recommends replication of the study in other sectors such as manufacturing, mining and public benefit organizations (PBOs). Further research is recommended on the variables interaction over a period of time using longitudinal methodology to especially study the influence of implementation of the strategic choices to the firm's performance.

\section{References}

Aguilera, R., \& Jackson, G. (2003). The cross-national diversity of corporate governance: Dimensions and determinants. Academy of Management Review, 28(3), 447-465. https://doi.org/10.2307/30040732

Bain, J. S. (1956). Barriers to new competition. Cambridge: Harvard University Press.

Baron, R. M., \& Kenny, D. A. (1986). The moderator-mediator variable distinction in social psychological research: Conceptual, strategic and statistical considerations. Journal of personality and social Psychology, $51,1173-1182$.

Boyd, B. K. (1995). CEO duality and firm performance: A contingency model. Strategic Management Journal, 16(4), 301-312. https://doi.org/10.1111/j.1467-8683.2009. 00748.x

Capital Market Authority (2015). Code of corporate governance practices for issuers of securities to the public 2015 (Cap. 485A), for both listed and unlisted public companies in Kenya. Kenya Gazette Notice No. 1420.

Carpenter, M., \& Westphal, J. (2001). The strategic context of external network ties: Examining the impact of director appointments on board involvement in strategic decision making. Academy of Management Journal, $4(4), 639-660$.

Child, J. (1972). Organizational structure, environment and performance: The role of strategic choice. Sociology, 6, 1-22. https://doi.org/10.1177/003803857200600101.

Child, J. (1997). Strategic choice in the analysis of action, structure, organizations and environment: Retrospect and prospect. Organization Studies, 18(1), 43-76. https://doi.org/10.1177/003803857200600101

Conner, K. (1991). A historical comparison of resource based theory and five schools of thought within industrial organization economics: Do we have a new theory of the firm? Journal of Management, 17(1), 121-154.

Daily, C., Dalton, D., \& Cannella, A. (2003). Corporate governance: Decades of dialogue and data, Academy of Management Review, 28(3), 371-382.

Dewji, H., \& Miller, S. (2013). Assessing the components of effective corporate governance. Strategic Management Review, 7(1), 47-63.

Essen, M., Oosterhout, H., \& Carney, M. (2011). Corporate boards and the performance of Asian firms: A meta-analysis. Asia Pac Journal of Management, 29, 873-905. DOI:10.1007/s10490-011-9269-1

Forbes, D., \& Milliken, F. (1999). Cognition and corporate governance: Understanding boards of directors as strategic decision-making groups. Academy of Management Review, 24(3), 489-505.

Freeman, R. E. (1984). Strategic management: A stakeholder approach. Massachusetts: Pitman.

Gellerman, S., \& Potter, R. (1996). 'The strategic question'. Business Horizons, 39(2), 5-10.

Hambrick, D. C. (2007). Upper echelon theory: An update. Academy of Management Review, 32(2), 334-343. 
Harrison, J., \& Wicks, A. (2013). Stakeholder theory, value and firm performance. Business Ethics Quarterly, 23(1), 97-124. https://doi.org/10.5840/beq20132314

Hendry, K., \& Kiel, G. C. (2004). The role of the board in firm strategy: Integrating agency and organizational control perspectives. Corporate governance. An International Review, 12(4), 500-520.

Heracleous, L. (2001). What is the Impact of Corporate Governance on Organizational Performance? An International Review, 9(3), 165-173. https://doi.org/10.1111/1467-8683.00244

Holderness, C. (2003). A survey of block holders and corporate control. Federal Reserve Bank of New York. Economic Policy Review, 9(1), 51-64. http://dx.doi.org/10.2139/ssrn.281952

Hoskisson, R. (1987). Multidivisional structure and performance: The contingency of diversification strategy. The Academy of Management Journal, 30(4), 625-644.

Israel, G. D. (1992). Sampling the evidence of extension program impact. Program evaluation and organizational development. IFAS: University of Florida.

Jensen, M. (1993). The modern industrial revolution, exit, and the failure of internal control systems. The Journal of Finance, 48(3), 831-880.

Jensen, M., \& Zajac, E. (2004). Corporate elites and corporate strategy: How demographic preferences and structural position shape the scope of the firm. Strategic Management Journal, 25, 507-524. https://doi.org/10.1002/smj.393

Judge, W. Q., Hu H. W., Gabrielsson, J., Talaulicar, T., Witt, M. A., Zattoni, A., Opez-Iturriaga, F. L, Chen, J. J., Shukla, D., Quttainah, M., Adegbite, E., Rivas, J., \& Kibler, B. (2015). Configurations of capacity for change in entrepreneurial threshold firms: Imprinting and strategic choice perspectives. Journal of Management Studies, 52, 506-530.

Kiel, G. C., \& Nicholson, G. J. (2003). Board composition and corporate performance: How the Australian experience informs contrasting theories of corporate governance. An International Review, 11, 189-205.

Lawal, B. (2012). Board dynamics and corporate performance: Review of literature, and empirical challenges. International Journal of Economics and Finance, 4, 22-35. http://dx.doi.org/ 10.18533/jefs. v4i02.21

Lipton, M., \& Lorsch, J. W. (1992). A modest proposal for improved corporate governance. Business Lawyer, 48, 59-77.

Machuki, V., \& Aosa, E. (2011). The influence of external environment on the performance of publicly quoted companies in Kenya. Business Administration and Management Journal. 1(7), 205-218.

March, J. G. (1991). Exploration and exploitation in organizational learning. Organization Science, 2(1), 71-87.

OECD (2004). Principles of corporate governance. Paris: OECD.

Parnell, J. (2013). Uncertainty, generic strategy, strategic clarity, and performance of retail SMEs in Peru, Argentina, and the United States. Journal of Small Business Management, 51(2), 215-234.

Pettigrew, A. (1992). On studying managerial elites. Strategic Management Journal, 13, 163-182.

Porter, M. (1981). The contributions of industrial organization to strategic management. Academy of Management Review, 609-620.

Pugliese, A., Bezemer, P., Zattoni, A., Huse, M., Van den Bosch, F., \& Volberda, H. (2009). Boards of directors' contribution to strategy: A literature review and research agenda. An International Review, 17(3), 292-306. https://doi.org/10.1111/j.1467-8683.2009. 00740.x

Scherer, F. (1980). Industrial market structure and economic performance. Chicago: Rand McNally.

Van Den Steen, E. (2013). A Formal Theory of Strategy. Harvard Business School, Boston, Massachusetts, 2616-2636. https://doi.org/10.1287/mnsc.2016.2468

Zohrabi, M. (2013). Mixed method research: Instruments, validity, reliability and reporting findings. Theory and Practice in Language Studies, 3(2), 254-262. https://doi.org/10.4304/tpls.3.2.254-262

\section{Copyrights}

Copyright for this article is retained by the author(s), with first publication rights granted to the journal.

This is an open-access article distributed under the terms and conditions of the Creative Commons Attribution license (http://creativecommons.org/licenses/by/4.0/). 